PART III

Faith, Doubt, and Duty 



\title{
Handwritten Reflections on Doubt
}

\author{
Undated
}

This handwritten fragment offers insight into Beerman's philosophical and theological disposition. While noting the perils of doubt, he also believed in its liberating quality, its catalyzing role in forcing us to probe and question in order to achieve enhanced understanding. Doubt figured in an even more profound way in Beerman's world. He devoted the entirety of his career to the rabbinate, but he was an unmistakable agnostic for whom faith in God was a doubt-ridden proposition. While he did not loudly broadcast this view, he did see doubt, in this sense, as an essential precondition to integrity and probity.

To be a man is to ask why in every dimension in life. To question, to doubt is a sure sign of our freedom and our reason. It is the image of God within us-our doubt is an essential element in our capacity to be creative.

But doubt is an ambiguous blessing. It is a sign of freedom. It can also be a sign of our defensivism, our inability to give ourselves over to a decision, a commitmentour distrust of genuine passion. Through the luxury of our unexamined doubts we can evade the responsibility of taking a stand, all the while pretending to be openminded. Doubt is our greatness but it can express our irresponsibility.

Some people are very free in their cultural doubt of traditional religious beliefs but quite unwilling to subject their capacity for objectivity to the same critical scrutiny.

The courage to doubt is the courage to risk one's own confidence in one's doubt.

Without doubt then can be no spiritual freedom, no integrity. With doubt there is the threat of utter meaninglessness. Whether doubt brings hope or hopelessness depends upon the individual's courage to accept doubt and its discipline. 


\section{COMMENTARY BY RABBI RACHEL TIMONER}

It was doubt that enabled Abraham to create Judaism. It was doubt that brought Abraham to believe.

In this handwritten exploration of the "ambiguous blessing" of doubt, Leonard beautifully associates doubt with creativity and spiritual freedom. Doubt is how we know that we are alive. Doubt is one expression of the image of God that is within us. Doubt is the active use not only of reason, but also of intuition and conscience, in the relentless pursuit of truth. Doubt is necessary for our species' intellectual, moral, and spiritual development. It is the foundation of the scientific method and the prerequisite for all social movements and all true religion. Only when we interrogate facts, doctrines, and tenets of faith do we become free to consider new possibilities. This is how meaning is made. Religion without doubt is stifling. Religion with doubt can be thrilling. But doubt has become its own religion, preventing us from committing to justice, to God, and to life. What I love most about Leonard's brief reflection is his warning that when doubt becomes an abdication of passion, a shelter from conviction, a failure of responsibility, it becomes cowardice. In the name of open-mindedness, we fail to take a stand. In the name of all truths, we fail to speak any truth.

Leonard was like Abraham. He first allowed doubt to free him from the constraints of inherited beliefs and conventional wisdom. But then he stood for his convictions with passion. He had both the courage to doubt and the courage to believe. 